\title{
Assortment of shrubs for different categories of green plants in settlements located in a dry region
}

\author{
Alexander Tereshkin, and Olesya Azarova ${ }^{1 *}$ \\ Saratov State Agrarian University named after N.I. Vavilov, 410012, 1, Theater square, Saratov, \\ Russian Federation
}

\begin{abstract}
The article is devoted to the study of the assortment of shrub species in various categories of green plants in settlements located in the arid region, using the example of the cities of Saratov and Engels. In practice, recommendations for choosing an assortment are used when choosing plants for landscaping. There are currently several sources for these recommendations. To determine the species diversity of shrubs and compare with the recommended assortment, authors examined the plantations of general use in the cities of Saratov and Engels. The predominant species of shrubs and their condition have been identified. The density of species growth on landscaping objects has been analyzed.
\end{abstract}

\section{Introduction}

In connection with the expansion of the territories of settlements and an increase in anthropogenic load, the relative share of green plants in the structure of cities is significantly reduced and anthropogenic loads on plantations increase. The use of ornamental shrub vegetation in urban plantations should be carried out by aesthetically attractive species with a high ecological tolerance to unfavorable urban conditions.

The fulfillment of the microclimatic, sanitary and hygienic, aesthetic and other useful functions inherent in green plants is largely determined by the species composition and the planting density. The stability and durability of both individual species and plantations in general in an urbanized environment depend on the range used and its compliance with environmental conditions $[1,2,5,9]$.

When selecting an assortment of plants for landscaping, in practice, zoning materials are used for the territory of Russia, which show the types of plants that can grow in a specific landscaping area. We have compared the species composition of shrubs recommended by A. I. Kolesnikov [6], L.B. Lunts [7], I. I. Galaktionov [3], V. I. Erokhin [4], T. A. Sokolova [10] for green building in Saratov and Engels. The analysis showed that L.B. Lunts included 94 species of shrubs for use, V.I. Erokhin - 91 species, I.I. Galaktionov. - 62 species. A.I. Kolesnikov recommends using 109 species to create landscape gardening and landscape construction, and T.A. Sokolova - only 70 ones.

*Corresponding author: azarovaov@yandex.ru 


\section{Methods}

To determine the species diversity of shrubs at public facilities in Saratov and Engels, we carried out an inventory of green spaces and compared with the recommended assortment [8]. We determined the planting density per hectare of territory.

\section{Results and discussion}

The composition of shrubs in the City Park of culture and rest named after Maxim Gorky located in Saratov includes 28 species. Half of them belong to flowering species, and the rest to decorative deciduous. Coniferous shrubs are not used enough in the compositions. Most shrubs are in good condition: Caragana arborescens Lam., Crataegus monogyna Jacq., Swida alba L., Viburnum opulus L., Cotoneaster lucidus Schltdl., Opulaster opulifolius (L.) Kuntze, Syringa vulgaris L., Symphoricarpos albus laevigatu Dill. ex Juss.

At the site under study there is an improvement organization that monitors the condition of trees and shrubs throughout the park. Only a small part of the shrubs is in a satisfactory and unsatisfactory condition: Juniperus sabina L., Juniperus media L., Berberis vulgaris L., Hydrangea paniculata Siebold, Frangula alnus Mill. These are mostly tapeworm plantings. Cleditchia triacanthos L., Crataegus oxyacantha L., Lonicera caprifolium L. and some other species are used singly.

Shrub vegetation in the Children's Park is represented by plantings of different quality in terms of their vital status. Such species as Amygdalus triloba Mill., Chaenomeles japonica Thunb. Lindl. ex Spach., Syringa microphylla L. and Camellia sinensis L. Kuntze are in good condition. These species are found in the territory as single plantings. More than half of the shrubs are in satisfactory condition: Juniperus sabina L., Caragana arborescens L., Viburnum opulus "Boule de Neige” L., Rosa canina L., Syringa vulgaris L., Symphoricarpus albus L. Blake and Syringa josikaea J Jacq ex Rchb. This is due to poor environmental conditions, as the park is surrounded by four roads, lack of agrotechnical measures and a high density of trees.

Most of the shrubs in the Park Lipki are represented by such species as Cotoneaster lucidus Schltdl, Symphoricarpos albus L. S.F. Blake. They are used as hedges. Syringa vulgaris L. occurs as single plantings, in a group with coniferous shrubs. Early flowering shrubs are Ribes alpinum L. Coniferous species of shrubs are represented by Juniperus horizontalis Moench. and Juniperus sabina L. Caragana arborescens Lam., Berberis vulgaris L., Viburnum opulus L., Rosa canina L. grow occasionally.

A large number of Cotoneaster lucidus Schltdl. Shrubs are concentrated in the Victory Park, which is represented by row plantings of hedges along the main avenues of the park. Syringa vulgaris L., Caragana arborescens Lam., Lonicera xylosteum L. are found in the form of group plantings and hedges on the slopes of the park, as well as in the central part. A significant number of Rosa majalis Herrm. and Amelanchier canadensis L. Medik grows on the site. Other deciduous shrubs are represented by Aronia melanocarpa Michx. Elliott, Crataegus monogyna Jacq., Swiden alba L. Opiz, Frangula alnus Mill., Symphoricarpos albus L. S. F. Blake. Coniferous shrubs are represented by Juniperus scopulorum Sarg. and Juniperus media P.J. van Melle.

Various varieties of Syringa vulgaris L. grow in the park of the First Teacher throughout the territory in the form of single and group plantings.

Throughout the studied area of Boulevard named after Rakhov, the predominant species are Cotoneaster lucidus Schltdl. and Syringa vulgaris L. Cotoneaster is used as a hedge along the entire perimeter of the boulevard, lilacs are used as single and group plantings. Other deciduous shrubs are represented by the following species: Caragana arborescens Lam., Rosa canina L., Rosa majalis Herrm., Spiraea japonica L.F., and Spiraea bumalda. 
In general, 46 species of shrubs grow in the plantations of general use in the city of Saratov, but their representation in the composition of the surveyed plantations varies greatly. Along with shrubs, most often in hedges, there are also bushy forms of trees Ulmus pumila L., Ácer negúndo L., Gleditsia triacanthos L.

The predominant species in the plantations of general use in Saratov are Cotoneaster lucidus Schltdl. Caragana arborescens Lam., Caragana arborescens Lam., Syringa vulgaris L., Philadelphus coronarius L. Species that occur in limited quantities include Rosa canina L., Lonicera caprifolium L., Crataegus monogyna Jacq., Symphoricarpos albus laevigatu Dill. ex Juss. Most species can be included in the group of singly occurring specimens. At the same time, 14 types of shrubs are not included in the lists recommended for use in landscaping objects in Saratov.

The study of the number of shrubs growing on the territory of the surveyed public facilities showed that there are 73798 plants growing on them. Of these, 38,944 (52.8\%) are in parks, $2,186(3.0 \%)$ in gardens, $3,624(4.9 \%)$ in squares, and in the plantings of the embankment and boulevard - 29044 (39.4\%), Table 1.

Table 1. The number and density of planting shrubs by categories of public facilities, Saratov.

\begin{tabular}{l|c|c|c|c|c|}
\hline \multicolumn{1}{c|}{ Index } & Parks & Gardens & Squares & $\begin{array}{c}\text { Street } \\
\text { plantings }\end{array}$ & $\begin{array}{c}\text { In } \\
\text { total }\end{array}$ \\
\hline $\begin{array}{l}\text { Area, ha } \\
\text { Number of } \\
\text { shrubs: }\end{array}$ & 110.9 & 7.2 & 2.1 & 15.4 & 135.6 \\
- in total, pcs & 38944 & 2186 & 3624 & 29044 & 73798 \\
$-\quad$ \% of total & 52.8 & 3.0 & 4.9 & 39.4 & 100.0 \\
$\begin{array}{l}\text { Density, } \\
\text { pcs/ha }\end{array}$ & & & & & \\
-factual & 351 & 303 & 1725 & 1886 & - \\
- & $2500-$ & & & & \\
recommended & 3000 & $1200-1500$ & $1000-1200$ & $3000-4000$ & - \\
\hline
\end{tabular}

It should be noted, the area of the surveyed objects is also unevenly distributed: the territory of parks is 110.9 hectares, of street plantings - 15.4 hectares, and only 7.2 hectares and 2.1 hectares are the area of gardens and squares, respectively. Therefore, it is more expedient to consider the number of shrubs per unit area in each of the surveyed categories and compare with the recommended standards for the density of planting shrubs at the corresponding sites. For comparison, the recommendations and generalizations by L.B. Lunts [7] were used, after which the actual planting density of shrubs on the surveyed categories of plantations was calculated.

According to Table 1, the density of shrubs does not coincide with the recommendations. In parks, their number is more than 7.5 times less than the normative data, in gardens - 4 times, in street plantings -2 times less, respectively. In the squares, in comparison with the normative indicators, there were more shrubs in 1.5-1.7 times. This is due to the wider use of hedges in the layout. In addition, in the practice of gardening and park construction, denser plantings on the territory of public gardens are often found, and thickened plantings are more preferable in an arid climate [7].

In order for green spaces to fully perform their functions in the surveyed public facilities, the planting density of shrubs must be brought up to standard indicators. To bring the planting density to the recommended, it is necessary to grow:

- 280 - 335 thousand pcs. of shrubs in parks;

- 9 - 11 thousand pcs. of shrubs in gardens;

- 46 - 62 thousand pes. of shrubs in street plantings. 
Thus, the simplest calculations show that in order to increase the aesthetic, sanitaryhygienic and microclimatic role of the plantations of general use, the city of Saratov only on the territory of the City Park of culture and rest named after Maxim Gorky, Victory Park, Park named after Yu.A. Gagarin, Park Lipki and park named after Radishchev, on the boulevard named after Rakhov and the Cosmonaut Embankment lacks from 335 to 408 thousand pcs. of shrubs.

It should be recognized that the assortment of shrubs used on the territory of the surveyed objects is quite wide, but the species and form diversity of conifers is extremely low. In recent years, there has been a tendency to expand the species composition of shrubs when planting greenery in public spaces during their reconstruction.

At all public facilities in the city of Engels, there is a lack of woody vegetation in accordance with the above standards. The lowest indicator of woody vegetation is observed in the park named after Pushkin ( $24 \mathrm{pcs} / \mathrm{ha})$. The number of shrub species at all public facilities is significantly lower than the established standards.

In the Square named after Lev Kassil most of the plants are in satisfactory condition (Viburnum opulus L., Syringa vulgaris L. and Prunus padus L.). Cotoneaster melanocarpus Fisch. ex Biytt. and Philadelphus coronarius L. are in good condition. Despite the location of the square near the roads, the bushes grow well due to agrotechnical tending.

Shrub vegetation in the Friendship Park located in Engels is represented by such species as Chaenomeles japonica Thunb. Lindl. ex Spach., Cotoneaster lucidus Schltdl. and Symphoricarpos albus L. Blake. These species are in good condition, they are resistant to urban conditions and are included in the list of the recommended assortment. Crataegus laevigata Poir DC., Syringa vulgaris L. and Philadelphus coronarius L. are in satisfactory and unsatisfactory condition.

On the territory of the Engels City Park, shrub vegetation is represented by plantings of different quality in terms of life. Berberis thunbergii DC., Opulaster opulifolius L. Kuntze, Swida alba L., Prunus padus L., Syringa vulgaris L. and Caragana arborescens L. are in good conditions These species are found in the territory as single plantings. More than half of the shrubs are in satisfactory condition: Juniperus sabina L., Juniperus media L., Cotoneaster lucidus Schltdl., Rosa canina L., and Symphoricarpus albus L. The dominant species in the Engels City Park are Syringa vulgaris L., planted singly and Cotoneaster lucidus Schltdl as a hedge.

The number and density of planting shrubs by categories of public facilities in Engels are shown in Table 2.

Table 2. The number and density of planting shrubs by categories of public facilities, Engels.

\begin{tabular}{l|c|c|c|c|c|}
\hline \multicolumn{1}{|c|}{ Index } & Parks & Gardens & $\begin{array}{c}\text { public } \\
\text { gardens }\end{array}$ & $\begin{array}{c}\text { Street } \\
\text { plantings }\end{array}$ & $\begin{array}{c}\text { In } \\
\text { total }\end{array}$ \\
\hline $\begin{array}{l}\text { Area, ha } \\
\text { Number of } \\
\text { shrubs: }\end{array}$ & 20.9 & - & 2.0 & 5.2 & 28.1 \\
$-\begin{array}{l}\text { in total, pcs } \\
\text { - } \% \text { of total }\end{array}$ & 2500 & - & 470 & 5200 & 8170 \\
$\begin{array}{l}\text { Density, } \\
\text { pcs/ha }\end{array}$ & 30.6 & & 5.8 & 63.6 & 100 \\
-factual & 119 & - & 235 & 1000 & - \\
- & & & & & \\
recommended & 3000 & $1500-$ & $1000-$ & & \\
\hline
\end{tabular}

In total, 21 species of shrubs were identified in the study areas in the city of Engels. The dominant species in Engels' plantations are Cotoneaster lucidus Schltdl., Cotoneaster melanocarpus Fisch. ex Biytt. Symphoricarpos albus laevigatus. Basically, they are planted 
in hedges around the perimeter of parks and squares and are in good and satisfactory condition.

Thus, in the plantations of general use in the city of Saratov, at present, it grows from 14 to 30 species of shrubs in parks, 7-15 in gardens, 6-9 in squares, and from 10 to 17 species in street plantings. In Engels, there are from 6 to 12 types of shrubs in parks, 5-7 species in squares, and from 5 to 9 species in street plantings. It should be admitted that the range of shrubs growing on the territory of the surveyed objects is quite wide, but specific variety of conifers is extremely low.

\section{Conclusion}

The generalized analysis of the data of shrubs inventory in the plantings of general use indicates low rates of the density of almost all objects of systemic landscaping in the cities of Saratov and Engels. The predominant assortment of shrub species in the city of Saratov and Engels is Cotoneaster lucidus Schlecht. and Syringa vulgaris L. Cotoneaster is widely found in public areas of cities and is one of the best species for hedges creating. The active use of lilacs in urban areas is associated with the high ecological tolerance and decorativeness of this species.

Syringa vulgaris L., Rosa canina L., Caragana arborescens Lam., Juniperus sabina L. are found in limited numbers. They can be found both in single plantings and in groups. Most of them are in satisfactory condition. Juniperus virginiana L., Prunus padus L., Spiraea japonica L., Berberis vulgaris L., Symphoricarpus albus (L.) Blake, Opulaster opulifolius (L.) Kuntze are mostly in good condition.

Shrubs, when properly spaced at the recommended density, can provide good protection from dust, smoke, noise and harmful gases. Thus, in the current conditions, it is necessary to increase the number of shrubs and expand their assortment according to the recommendations. A wide range of shrubs will make it possible to create ecologically plastic plantations that will have not only high decorative, but also ecological functions.

\section{References}

1. P. N. Proezdov, D. A. Mashtakov, Yu. V. Barinov, Int. Scientific Conference "Investment, Construction, Real Estate: New Technologies and Special-Purpose Development Priorities» (ICRE, 2018)

2. F.M. Lelkhova, The World of Science, Culture, Education, 85, 6 (2020)

3. N. V., Polyakova, F. K. Murzabulatova, Hortus botanicus, 12 (2017)

4. L. S. Ivlev, Academy, 32, 5 (2018)

5. O. A. Sorokopudov, A. V. Artyukhova, Hortus botanicus, 12 (2017)

6. V. Tobias, S. M. Fedorov, Biological Communications, 4 (2011)

7. B. Marchenko, Hortus botanicus, 10 (2015)

8. O. I. Nedoseko, Russian Journal of Ecosystem Ecology, 4 (2018)

9. A. Firsov, V. V. Byalt, A. V. Byalt, Hortus botanicus, 13 (2018)

10. N. B. Prokhorenko, V. G. Demin, proceedings of the Samara scientific center of the Russian Academy of Sciences, 18 (2016) 